A second motion directed attention to the essential need for the elimination of atomic weapons and for a strict international control and inspection of atomic installations. It stated that the differences in policy on international control between the various countries are not as great as has sometimes been suggested and are capable of resolution by compromise. It continued: "In particular, the stress that has been laid on international ownership of large-scale atomic establishments is not justified. Although such ownership might facilitate control it is not essential for effective control. Since it constitutes a major stumbling block we respectfully suggest to our Government that it should use its influence to secure that this proviso is not allowed to hold up a general agree. ment".

Further resolutions were passed establishing a National Committee and deciding that membership shall be open to natural and social scientists, technologists, engineers and technical assistants and to students taking appropriate courses. Members may join individually or through groups. The twenty-five members of the National Committee include Prof. L. Rosenfeld, Prof. A. C. Offord, Prof. F. G. Gregory, Mr. N. W. Pirie, and Prof. J. D. Bernal. Prof. Kastler and Dr. Grillot were present as fraternal delegates from the French organization "Mouvement des Universitaires Français devant la Menace d'une Nouvelle Guerre Mondiale". Both addressed the conference, and stressed that peace organizations must achieve extensive international contacts.

Summing up the conference, Prof. C. F. Powell said that the whole of West-European scientific tradition from the time of Bacon and Descartes is based on the view that by means of science it is possible to enrich life. The current tendencies towards secrecy and victimization may sap our scientific life like a wasting disease and completely undermine the scientific traditions of Great Britain. In so far as we contribute to the release of tension among the nations, we contribute not only to the safety and independence of our country, but also to the support and sustenance of the great scientific tradition in which we have been fostered and to removal of the suspicion that scientists are indifferent to the often revolutionary consequences of their own discoveries. F. G. GREGORY

\section{ABRASION AND WEAR OF MATERIALS}

A

SYMPOSIUM on the "Abrasion and Wear of Materials" was held under the auspices of the British Society of Rheology on January 4 at the Polytechnic, Regent Street, London. Of the six papers delivered, three, read in the first session, dealt with hard inorganic materials; the remaining three were devoted to the abrasion and wear of rubber, textiles and leather.

The symposium was opened by M. W. Thring (British Iron and Steel Research Association, London), who was chairman for the morning session. In the afternoon, Dr. V. G. W. Harrison (Printing, Packaging and Allied Trades Research Association, Leatherhead) was in the chair. In the first paper, P. Grodzinski (Diamond Research Laboratory, Industrial Distributors, Ltd., London) described "Three Years Experience with a New Micro-Abrasion Tester". Mr.
Grodzinski has developed a tester, primarily for determining vector-hardness differences in diamond surfaces, which has, however, proved useful for most hard materials. The equipment comprises essentially a sharp-edged, doubly conical wheel of 1 in. radius, made of sintered carbide impregnated with diamond dust and revolving at 10,000-15,000 r.p.m., against the edge of which the sample is pressed by a balance arm at low load. The dimensions of grooves cut in 1-15 sec. at given pressures serve as measures of hardness, and in the case of hard materials such as diamonds, rubies and carbides, these are linearly related to their hardness as determined by conventional methods.

Dr. K. H. R. Wright (Mechanical Engineering Research Organization, Department of Scientific and Industrial Research, Glasgow), in a paper entitled "Fretting Corrosion", described a series of experiments of a fundamental nature, in which he carefully controlled environmental and mechanical conditions such as humidity, surface adsorption of oxygen, etc. The oxide initially formed in the fretting corrosion of steel was $\mathrm{Fe}_{3} \mathrm{O}_{4}$, but ultimately $\alpha-\mathrm{Fe}_{2} \mathrm{O}_{3}$ was found. Experiments were carried out with steel submerged in British Pharmacopoia paraffin which was either free from water or saturated with it. In each case the formation of $\alpha-\mathrm{Fe}_{2} \mathrm{O}_{3}$ could be inhibited, but this was not possible if the metal was immersed in $n$-hexane, an inert liquid with a high content of dissolved oxygen. Lubricated, phosphated steel surfaces were very resistant to fretting corrosion, but nickel-plating, contrary to belief, was ineffective as inhibitor.

A paper entitled "The Wear of Wire-Drawing Dies" was read by J. G. Wistreich (British Iron and Steel Research Organization, Sheffield), whose research is directed towards reducing materially the frequency of failure of sintered-carbide wire-drawing dies, for failure is at present a source of considerable economic loss by causing periods of enforced idleness in wiredrawing mills. The most serious form of failure is 'ringing', in which ring-shaped cavities are formed near the die entry and exit. Carbide grains loosened in that region detach themselves on drawing the wire, scoring the latter in the process and facilitating damage to subsequent dies. Evidence from a statistical analysis of die-failures shows that, although short die-lives are prevalent in the correlation of frequency with lengths of die-lives, a tail exists in the distribution curve at its long-lives end. This indicates that a practical solution might be found, most probably by improving the methods and means of die-lubrication.

Speaking on "Elementary Aspects of Rubber Abrasion", Dr. A. Schallamach (British Rubber Producers Research Association, Welwyn) said that the scratch-traces produced by the movement of a loaded needle, and the corresponding tractive forcetime records, depend pronouncedly upon the nature of the compounds under investigation. Traces on pure gum vulcanizates are always continuous, but those on carbon-loaded compounds of the tyre-tread type are discontinuous. Abrasion patterns have proved to be an important clue to the actual mechanisms by which abrasion of tyres occurs on the road.

Dr. T. H. Morton (Courtaulds, Ltd., Bocking, Essex), in a paper on the "Wear and Abrasion of Textiles", said that, since the application of an abrasive to a textile material can produce a hole similar to that resulting from wear, there exists a tendency to equate abrasion with wear, though it is 
now known that wear can be ascribed to abrasion, flex-fatigue and the mechanical unravelling of the fabric structure, with abrasion not necessarily the most important contributor. Energy is absorbed by the fabric in abrasion, which fact provides the keystone to the recent theories of Hamburger in which tensile and abrasion properties are correlated.

H. Bradley (British Boot, Shoe and Allied Trades Research Association, Kettering), speaking on "The Abrasion and Wear of Leather", surveyed the progress made in this field in recent years. In spite of much work it has not so far proved possible to design wear-testing equipment for the rapid assessment of the wear of leather under practical conditions, and the issue of free shoes to schoolboys still provides the most reliable means for wear-testing. Dimensional analysis was suggested by Mr. Bradley as a possible basis for future research.

P. Feltham

\section{EARTHQUAKES DURING 1951}

$\mathrm{D}$ URING 1951 fourteen earthquakes caused major damage and casualties. The swarm of shocks which started on Boxing Day 1950 continued daily in the Leeward Islands during January. On Nevis, severe damage was done to the library, the hospital and to most public buildings, as also to two churches, two or three schools and the school feeding-centre. Demolition was necessary in some cases, and there was concern over the water supply. On St. Kitts two banks, the treasury and the hospital, together with some private houses and business premises, were damaged. Most of the people in these islands live in small wooden houses, which were not damaged by the shocks, and fortunately there was no loss of life or food shortage.

In New Zealand a swarm of shocks occurred during January at Cheviot, a small town sixty miles north of Christchurch. The first shock, on January 10, had magnitude $5 \cdot 6$ on the Richter logarithmic scale, and there followed some twenty-five other strong shocks during the month. Most of the chimneys in Cheviot were down, the telephone service was temporarily out of order and the Blenheim-Christchurch railway was temporarily blocked by a landslide.

A series of tremors, culminating in two strong shocks on January 14, caused heavy property damage at Angrado Heroismo in the Azores.

On March 14 earth tremors rocked parts of France, Belgium, Holland and Germany. The epicentre was probably in the Eifel plateau, and at Euskirchen the walls of a school cracked and the chimney fell down. Minor property damage in the area was extensive. On April 8 an earthquake near the coast of Turkey $\left(37^{\circ}\right.$ N., $35^{\circ}$ E.) caused casualties amounting to six killed and ten injured.

Four destructive earthquakes occurred during May. On May 6 approximately a thousand people were killed, four thousand injured, and twenty thousand rendered homeless by the earthquake which wrecked the town of Jacuapa in the Republic of El Salvador. Jacuapa is some seventy-five miles east of San Salvador. On May 10 a tremor shook southern Rhodesia, and a further twenty-four tremors continued to shake the same area during the month. A large landslide was caused by the earthquakes in the Chimanimani mountains. On May 19 an earthquake near Cordova in Spain caused such damage to the convent of St. Francis that it later collapsed. No casualties were caused, as the building had been evacuated following the initial damage. On May 31 an earthquake off the north coast of Luzon $\left(19^{\circ}\right.$ N., $121^{\circ}$ E.) in the Philippine Islands caused slight property damage, and injury to one person.

On July 9, near the east coast of Oaxaca, Mexico, one person was killed as a result of an earthquake at Miahuatlan.

On August 13, at 18h. 33m. 40s. G.M.T., a strong earthquake occurred in the Black Sea, off the coast of 'I'urkey. In the district of Kurshunlu in the province of Changari, several villages were razed and the official report states that 3,354 houses were destroyed, resulting in 50 people being killed and 208 injured. On August 21 an earthquake with epicentre near the west coast of Hawaii caused some damage to property on the Kona coast.

On October 22 , at 03 h. $29 \mathrm{~m}$. 26s. G.M.T., For mosa was shaken by a tremor which proved to be the first of a series of more than forty heavy and more than ninety minor earth tremors. The main business centre of Hualien was wrecked ; more than twenty bodies were recovered from the debris. Houses were also damaged in Tainan and Taichung. Reports state that approximately a hundred people were killed and eight hundred injured in the island. Again, on November 12, earth tremors damaged the port of Hsinkiang on the east coast of Formosa, but on November 24 a series of shocks, the greatest being at $18 \mathrm{~h} .50 \mathrm{~m}$. 19s. G.M.T. (Richter logarithmic magnitude $7 \frac{1}{4}$ ), once more shook the east coast, causing major property damage and the deaths of twelve persons. Several others were injured.

Of the earthquakes so far mentioned, only the lastnamed attained a Richter logarithmic magnitude greater than 7 , but all happened in populated districts. During the year, six other earthquakes, with epicentres in unpopulated areas, attained a Richter logarithmic magnitude greater than 7. These were on February 17 in south-east New Guinea (71),

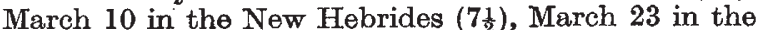
Kermadec Islands $(7 \cdot 1)$, November 6 in the Kurile Islands (71), November 18 in eastern Tibet $\left(7 \frac{1}{2}\right)$, and December 8 in the Indian Ocean, about nine hundred

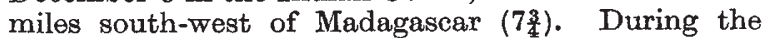
year seven earthquakes had a depth of focus greater than $250 \mathrm{~km}$. These occurred on February 9 in the Pacific Ocean between Tonga and the Kermadec Islands $(600 \mathrm{~km}$.), March 23 (previously mentioned) in the Kermadec Islands $(300 \mathrm{~km}$.), July 11 in the Bonin Islands region $(550 \mathrm{~km}$.), August 2 near the New Britain Islands $(500 \mathrm{~km}$.), August 10 off the north coast of Hokkaido (Japan) $(300 \mathrm{~km}$.), August 28 . in the Kermadec Islands region $(600 \mathrm{~km}$.), and November 12 south of the Fiji Islands $(400 \mathrm{~km}$.).

The above account is based on information received from the International Seismological Association (Strasbourg) and co-operating observatories, the Jesuit Seismological Association of Observatories (headquarters St. Louis, United States), the United States Coast and Geodetic Survey with its seismological observatories, Stuttgart and the adjoining stations, Zurich and the Swiss observatories, Wellington and the New Zealand observatories (including Fiji), Aberdeen, Belgrade, Cleveland (Ohio), De Bilt (Netherlands), Durham, Karlsruhe, Kew, Mizusawa (Japan), Pasadena, Perth (Western Australia), Toledo and Trieste.
ERnEst 'TiLLOTSON 